\title{
DEMOCRATIZATION IN SERBIA: AN ANALYSIS OF RATIONAL CHOICE AND STRUCTURALIST EXPLANATIONS
}

\author{
Dunja Apostolov-Dimitrijevic \\ Carleton University
}

\begin{abstract}
This paper explains political democratization in Post-Milosevic Serbia, utilizing two different accounts of the democratization process: one rooted in the rational choice framework and the other in structuralism. While rational choice explains the decisive role of political leadership in overcoming path dependence, the structuralist explanations show the transnational linkages that encourage democratization in the face of domestic setbacks. This particular debate between the two types of explanations represents the larger debate concerning the role of internal factors and external linkages in propelling democratization in transitional societies. The paper concludes by integrating the two sets of explanations offered by each theoretical perspective, in order to develop a coherent understanding of Serbia's democratization.
\end{abstract}




\section{Introduction}

Since the ouster of Slobodan Milosevic from power in 2000, Serbia has been on a path towards democratization. It has sought to introduce democratic principles through institutional reform, to protect human rights and secure the rule of law (European Commission 2013). Serbia has undertaken extensive liberalization and has begun to restructure its economy (ibid.), which has had direct political effects as new actors have emerged from these processes to contest political power. In addition, Serbia has strengthened its ties with Western democracies by joining or seeking membership in institutions such as the Organization for Security and Cooperation in Europe (OSCE), the European Union (EU), the International Monetary Fund (IMF), and the World Trade Organization (WTO). Membership in these organizations has been the key to pursuing political and economic reforms that have reinforced Serbia's democratizing efforts.

While the decisions to implement democratic reforms may seem straightforward given the extensive democracy promotion assistance during the Milosevic era (Presnall 2009; Spoerri 2010) as well as subsequent democracy promotion initiatives (Edmunds 2009, 129), it should not be taken for granted. Key institutions have resisted democratic reform (Edmunds 2008; Bieber 2011) and segments of Serbian society have expressed affinity for the values of authoritarian collectivism and redistributive statism (Lazic and Cvejic 2007). Given the latter, this paper will outline two different accounts of the process of democratization in Serbia - one rooted in rational choice or voluntarism, the other in structuralism. ${ }^{1}$ The paper will argue that both approaches contribute to the understanding of democratization in Serbia. Explanations rooted in the rational choice framework give insight into the decisive role of political leadership in overcoming path dependence. Structuralist explanations are well-attuned to the transnational linkages that encourage democratization in the face of domestic setbacks. As will be evident in the paper, these rational choice and structuralist explanations also speak to the larger debate concerning the role of internal factors and external linkages in propelling democratization in transitional societies (see: Schimmelfennig and Sedelmeier 2005; Pridham 2005; Vachudova 2005; Levitsky and Way 2010).

In making the above argument, this paper will begin by outlining the major tenets of rational choice theory and will then provide an account of democratization in Serbia through the latter lens. The paper will then briefly outline structuralist explanations, followed by an account of Serbia's democratization through the structuralist lens. The paper will conclude with a discussion and analysis section, in which it will make the case for integrating the two sets of explanations, in order to develop a coherent understanding of Serbia's democratization.

\footnotetext{
${ }^{1}$ While it is difficult to separate the two accounts, to provide a perspective on the transition that is "entirely voluntarist" or "entirely structuralist," as both structures and purposive actors played some role in democratic transition and consolidation, the two theoretical orientations will be kept distinct for the purpose of this paper in order to highlight the contrasting points of emphasis in each perspective.
} 


\title{
Rational Choice Theory and its Explanations of Democratization in Serbia
}

\author{
Rational Choice: Tenets, Assumptions, and Implications
}

Barbara Geddes (2003, 191) outlines the four defining features of rational choice as: (1) methodological individualism (applied to people and those organizations that can plausibly be expected to behave as unitary rational actors); (2) explicit identification of actors and their goals or preferences; (3) explicit identification of the institutions and other contextual features that determine options available to actors and the costs and benefits associated with different options; and, (4) deductive logic. In rational choice approaches, there is a focus on individualized actors/units, as opposed to social groups or institutional arrangements, which are the focus of the various strands of institutionalism ${ }^{2}$. In contrast to holism, which holds that social structures cannot be reduced to independently-existing agents and their interactions, methodological individualism treats social scientific explanations as reducible to properties or interactions of independently-existing individuals (Wendt 1999, 26). Explaining social scientific phenomena from the perspective of methodological individualism implies that objects of study are a product of bottom-up voluntary processes. Actors within this framework have agency and are intentional, purposive, and strategic. They are able to undertake a cost-benefit calculus on a potential course of action and take into consideration the choices and actions of others in pursuing their aims (Levi 1997, 23).

In addition, rational choice directs us towards an examination of actors in light of the goals that they wish to achieve. According to Geddes (2003, 179), rational choice approaches assume that people choose the means most likely to result in desired ends, can order their goals, and hold consistent preferences. To say that actors are rational means that, given goals and alternative strategies from which to choose, actors will select those that maximize their chances of achieving their goals (Levi 1997, 23). Rational choice does not argue that actors will act on the basis of what is objectively and universally rational, or that they will act in such a way as to produce an efficient equilibrium. Rather, it argues that individuals will act in a way that is consistent with their preferences. According to both Levi (1997) and Geddes (2003), rational choice recognizes constraints on behaviour (both societal and institutional). What it does not recognize is the ability of institutional and societal constraints to shape identities in such a way that actors are no longer seen as autonomous and analytically distinct from the structures that constrain them.

Within the literature that examines transitions to democracy, voluntarist approaches dominated explanations of the Third Wave of democratization (defined as the wave of transitions from autocracy in the capitalist world that began with Portugal in 1974) (McFaul, 2010). Studies such as those conducted by O'Donnell and Schmitter (1986) de-emphasize structural characteristics in favour of an analysis of key actors, negotiations (or lack thereof) between them, and choices made at critical points in time. Similarly, Przeworski (1991) examines democratic development by looking at negotiations between those associated with the previous authoritarian regimes and allies in the struggle against democratization. More recently, voluntarist aspects have been considered in the study of diffusion effects (regarded as a structural determinant in transitions). Here, Weyland (2006; 2010) looks at the way in which domestic actors respond to the diffusion

\footnotetext{
${ }^{2}$ For an overview of the various strands of institutionalism, see Hall and Taylor (1996). For an account of discursive institutionalism, see Schmidt (2008).
} 
of ideas across borders, arguing that domestic actors can choose whether or not to respond and appropriate ideas that originate beyond their borders.

\section{A Rational Choice Account of Serbia's Democratization}

While it must be emphasized that under Geddes's account, understanding transitional democracies through rational choice accounts is problematic because "the rules and players have not become established and actors have had no time to learn about the new system" (Geddes 2003, 185), this paper will nonetheless examine Serbia's democratization through the lens of rational choice. I do this because I think that a rational choice perspective, through its focus on actors, preferences, strategic interaction, and the cost-benefit calculus, provides insight into the decisive role of leadership in initiating and encouraging democratization.

As mentioned above, rational choice directs our attention towards actors and their goals. Hence, under a rational choice account of democratization, I focus on the various illiberal elements in the political system, the pro-democracy faction, and its actions. In the immediate aftermath of Milosevic's fall, the pro-democracy faction was brought to power, representing a shifting coalition of political parties that supported the EU's agenda in Serbia (of democratization and liberalization). I treat the pro-democracy faction as a unitary entity for the purpose of detailing the rational choice explanation. However, I do not hold that the membership in the prodemocracy faction has been constant. This paper acknowledges that, from 2000 to 2003, Kostunica and Djindjic (who was assassinated on March 12, 2003) were the leaders of the prodemocracy faction; between 2003-2006, it was Kostunica and Tadic; and from 2006-2010, it was Tadic alone, as Kostunica became more closely associated with the anti-democracy faction (Gordy 2001, 13). What this paper does hold is that the membership in the pro-democracy faction had a constant preference to pursue democratic reforms and further Serbia's relationship with the EU, while the anti-democracy faction had anti-democratizing tendencies and preferred to cut off Serbia's relations with the EU.

Following Geddes's point that rational choice approaches necessitate explicit identification of institutions, contextual features, and actors, it is important to note the institutional and social context within which the pro-democracy faction pursued its policies of democratization. ${ }^{3}$ To understand why Kostunica and Djindjic were able to become the main leaders of the prodemocracy faction in the post-Milosevic era, it is important to note the legitimacy they gained not only in leading the forces that toppled the Milosevic regime, but also in their own opposition to authoritarianism (Krnjevic-Miskovic 2001, 97), which quickly allowed them to form and maintain the two largest pro-democracy parties in the country. The pro-democracy faction was opposed by a group of political parties (i.e. the anti-democracy faction referred to above) that were united primarily by a desire to avoid entry into the European Union, and encompassing a variety of conservative, nationalist elements (Pond 2009; Krnjevic-Miskovic 2001). Other actors in the equation were the social and economic elite, which largely profited from the criminalization of the Serbian state under Milosevic (Edmunds 2009, 130) and switched sides with the intent of preserving their own interests once the Milosevic regime collapsed (Gould and Sickner 2008, 761).

\footnotetext{
${ }^{3}$ For an overview of actor dynamics and context in the lead-up to the fall of the Milosevic regime, see Bunce and Wolchik (2011).
} 
The voting public was divided into cleavages that could not be easily transferred into support for a liberal democratic system (for an overview of political cleavages in Serbia in the 1990s, see Jou 2010). On the one hand, society exhibited collectivist values and a preference for distributional social norms that were rooted in the previous socialist command economy and agrarian relations that persisted until World War II (Lazic and Cvejic, 2007: 57). On the other hand, these attitudes were juxtaposed against emerging individualist values that were a product of the modernization of the socialist period and openness to the West (ibid.). It was argued that Serbs saw elections as largely procedural, as a way to legitimize existing leadership, yet at the same time, popular mobilization was not uncommon as massive social protests were responsible for progressively weakening the Milosevic regime (Bunce and Wolchik 2011).

Within this context, a rational choice approach would explain the implementation of democratic reforms in Serbia as a result of the purposive action on the part of the pro-democracy faction. Focusing on the micro-processes that were behind the implementation of the democratic reform package, it would stress the cost-benefit analysis of the pro-democracy faction. Being able to align oneself with the pro-democracy social movements and civil society that toppled the Milosevic regime (Edmunds 2009, 138) meant harnessing the benefits of popular support at election time. Reinstating Serbia's membership in the United Nations (UN) and the OSCE, as well as joining the Stability Pact for Southeast Europe (and later, the Stabilization and Association Process (SAP), which offered Serbia the prospect for eventual EU membership), the European Bank for Reconstruction and Development (EBRD), the IMF, and the Council of Europe, carried financial rewards and social prestige. These were especially important for a country that was treated as an international pariah and was in need of economic investment (Bunce and Wolchik 2011, 88). Given that the anti-democracy faction was advocating a policy that would have contributed to Serbia's isolation from the international community, one could say that the pro-democracy faction calculated that the benefits of democratization outweighed the costs.

Yet, it is not enough to postulate that actors behaved consistently with preferences; one must also show that actors were able to act strategically - that is, with agency, and with attention to the choices and actions of others. Several examples will illustrate the latter. First, major obstacles to democratization included the many state institutions, such as the state security and intelligence agencies, which contained illiberal elements (Edmunds 2009; Gordy 2004, 15). As noted by Edmunds (2009, 128) even in the face of unprecedented internal and external pressures for democratic change, illiberal interests, actors, and networks found ways to survive, adapt, and even thrive. However, in the context of subsequent democratization efforts, the pro-democracy leadership was successful in negotiating a limited, secret pact with the Serbian intelligence and security agencies in support of democratization (Edmunds, 2008). The arrangement resulted in these institutions not directly interfering with political reforms, and passively supporting the leadership, so long as their own organizations and members were left alone (ibid.). Thus, through negotiation with the various elements that opposed democratization, the pro-democracy leadership was able to create a precarious but viable equilibrium between themselves and their opponents. This equilibrium was based on purposive action in which a steady process of democracy promotion and state stability was prioritized to the outright elimination of antidemocratic elements. As part of a voluntarist account, one could argue that this equilibrium was an outcome of an assessment made by the pro-democracy faction to compromise with illiberal 
elements in the short run, in order to enable a more general implementation of the democratic package in the long run. This interpretation parallels the actor-centered explanations found in the seminal work of O'Donnell and Schmitter (1986) which notes the pacts made between the new pro-democracy regimes and the remnants of the authoritarian regime in order to ensure stability of the democratization process.

Another example of strategic interaction concerns Serbia's relations with Kosovo and the Albanian ethnic minority in central Serbia. The example is telling of the ability of the prodemocracy leadership to overcome political opponents and institutional resistance (e.g. state intelligence, the Serbian Orthodox Church) towards progressively creating positive neighbourly relations with Kosovo and improving minority rights in Serbia. The modern source of ethnic tensions in Kosovo between Kosovo Albanians and Serbians is a result of political decisions and demographic trends that have their roots in the policies of the Socialist Federal Republic of Yugoslavia (Djurdjev, 2000:133-138). In the post-Milosevic period, the instability in Kosovo had spillover effects within central Serbia, as five districts with predominantly Albanian populations have a similarly confrontational relationship with the Serbian state. While many Serbian policy-makers saw these domestic minority populations as a growing threat repeating the scenario that played out in Kosovo, the pro-democracy leadership successfully took an alternative approach. Between 2006 and 2010, the pro-democracy leadership integrated regional (ethnic) political parties into joining the pro-EU coalition, thus marginalizing key anti-EU parliamentarians to enable the implementation of minority rights laws within Serbia and facilitate cooperation with Kosovo's separatist authorities (post-2007). The result of these actions was the beginning of a process of de-escalation of regional tensions, which supported the EU's requirement for good neighbourly relations among the former Yugoslav republics. In fulfilling its political obligations towards the EU, the pro-democracy faction was able to reinforce the externally-supported democratization effort.

Taken together, the central aspects to these rational choice accounts are the centrality given to factions and the interaction between the pro-democracy actors and the various illiberal elements in Serbia. What both of the previous examples emphasize is the pro-democracy faction acting autonomously from the anti-democratic structures, yet strategically, taking into account the presence of anti-democratic elements, such as the security apparatus and nationalist parliamentarians. Harnessing public support, financial rewards, and social prestige were the benefits associated with the pro-democracy reforms. International isolation, especially at a time when Serbia faced concurrent economic and social pressures, was a significant cost to not pursuing the democratizing initiatives and not engaging with the EU.

\section{Structuralist Accounts and their Explanations of Democratization in Serbia}

\section{Structuralist Accounts: Tenets, Assumptions, and Implications}

Just as rational choice assumptions have been adopted by a variety of frameworks, so structuralist assumptions are implicit within various theoretical frameworks. Whether examining historical, sociological, or discursive institutionalism (Hall and Taylor 1996; March and Olsen 1998; Schmidt 2008), the common thread running through these structuralist perspectives are the 
patterns of social relations created through interaction. Whereas, under a rational choice account, the starting point of analysis is the individuals or some analogue to the individual (Geddes 2003, 177), structuralist accounts focus on the arrangements between the various components of the social system - the structure - and how these shape both the identities of actors and their behaviours.

Paralleling the individualist/holist distinction identified above, whereas rational choice assumes that social scientific phenomena can be explained through the interaction of individual actors acting voluntarily and autonomously, structuralist approaches argue for a top-down influence of structure on agents. Actors may be differently positioned within the system of structural constraints, and this affects both the extent and nature of their agency. Systemic constraints are regarded as rewarding behaviours that conform to existing patters of interaction, while discouraging those behaviours that disrupt, violate, and challenge existing patterns. Moreover, voluntarist accounts' focus on purposive and strategic actors can be interpreted as a focus on the demand side of social relations - the various groups that promote, support, and implement prodemocracy reforms. Structuralists, on the other hand, can be interpreted as emphasizing the supply side of the equation, such as a country's institutional arrangements or political economy, as they examine the extent to which respective environments are hospitable to democratization.

While institutionalist approaches tend to be state-centric in focus ${ }^{4}$, international structures, such as structures of capital (see Cox 1986; Robinson 2004) or ideational structures (see Wendt 1999), have also been argued for in the academic literature. Like structures at the nation-state level, international structures make certain courses of action more difficult to implement than others. For example, Waltz (1979) famously argued that the anarchical structure of the state system makes it difficult for states to overcome the imperatives of the security dilemma. However, unlike national structures, international structures focus on the patterns of interaction that take place beyond any one nation-state and work to shape the identities and behaviour of both states and individuals alike.

Structuralist explanations of democratization in transitional societies point to institutional structures and, especially with the Fourth Wave of democratization, the international system and its role in encouraging or discouraging democratization. Hence, Levitsky and Way (2010, 23) argue that the capacity of competitive authoritarian incumbents to hold onto power hinges on two factors: (i) linkage to the West - density of economic, political, diplomatic, organizational, and social ties between particular countries and the United States or the EU; and (ii) incumbents' organizational power, or scope and cohesion of state and governing-party structures. McFaul (2010), in his edited volume, Democracy and Authoritarianism in the Postcommunist World, similarly focuses on international structures, but does so from the perspective of systemic structures (i.e. uni- versus bi-polarity). He argues that the international system's causal role in encouraging democratization is the "missing variable" in much of the research on postcommunist transitions. In both accounts, the conduciveness of the international dimension (whether in terms of international institutions or systemic structures) to supporting democracy within nation states is a key independent variable. The international dimension in both accounts exercises a decisive

\footnotetext{
${ }^{4}$ As an example of this, note the definition of historical institutionalism found in Hall and Taylor (1996, 938): "formal or informal procedures, routines, norms and conventions embedded in the organizational structure of the politu... [emphasis added]."
} 
influence on behaviour, so that the starting point of one's analysis can no longer be national actors acting on the basis of voluntary preferences.

\section{Structuralist Accounts of Democratization in Serbia}

A structuralist explanation of democratization in Serbia would stress the way in which EU programs and conditionality on the one hand, and changes in political economy on the other, are conducive to democratization. An explanation that looks at the former would stress the linkages between the EU and Serbia that are being formed through the EU's policy framework for the region - the aforementioned Stabilization and Association Process (SAP). The SAP is a threefold instrument that offers potential candidates trade liberalization with the EU, financial assistance, and a possibility of EU membership, provided that countries party to the agreement meet the required conditions of membership (Elbasani 2008, 269; 298-299). The conditions involve the adoption of democratic principles, protections of human rights and the rule of law, protection of minority rights and market reforms (as set out in the European Commission's "Report on Enlargement" [1993, 11-12]). A structuralist explanation would interpret these linkages as anchoring Serbia to the norms, policies, and institutional arrangements of the EU, thereby limiting the scope of policy options available to domestic actors.

To implement the SAP, the EU integrates prospective members into various political, social, and economic networks that further consolidate the EU as a structural influence. Various people-topeople contacts through visa-free travel for candidate countries, scholarships for students, and cooperation in areas of science and research, education, culture, youth, and media are offered. Membership in expert networks, such as the Regional Centre for Combating Trans-border Crime and the South Eastern Europe Organized Crime Threat Assessment, are facilitated under the SAP. Moreover, networking initiatives among civil society groups in the EU and candidate countries are encouraged. ${ }^{5}$ These opportunities together, and over time, forge connections that condition choices. They create constituencies whose interests and identities become aligned with those of the EU and their citizens. Together, the patterns of relations established through membership in networks and the conditionality mechanism condition both the identities and choices available to domestic actors, allowing the EU to exert a structural influence over Serbia.

The progressive convergence in party platforms could be cited as an example of the way in which transnational linkages exercise a structural influence on domestic actors. In order to receive the manifold benefits of EU membership, Serbia's governments need to make progress towards meeting EU membership criteria. The EU's good opinion is a key factor in the decisions of foreign investors; credit agencies adjust credit ratings in reaction to EU assessments and the release of EU progress reports (Vachudova 2010, 101). As a result, whereas at the outset of the post-Milosevic period, the main political parties in Serbia diverged significantly over the question of democratization and EU membership (Radeljic 2014), they have progressively converged over both. Currently, the main political parties, including the governing party that had ties to the most ideologically and politically nationalist elements in Serbia's political class (the Radical Party of Vojislav Seselj), are in favour of democratization and EU membership (Balkans in Europe 2014). Structuralist explanations would state that the convergence in party platforms is

\footnotetext{
${ }^{5}$ For an overview of the networks of EU connections being encouraged, see the European Commission's "Western Balkans: Enhancing the European Perspective" (2008).
} 
not the result of political parties independently forging preferences towards democratization. Rather, and as noted by Vachudova (2005) in the case of East European states, it is a consequence of EU linkages that progressively condition the various parties towards adopting pro-democracy reforms.

Changes in political economy are equally important to note under structuralist explanations and are rarely acknowledged by voluntarist accounts. In Serbia's case, liberalization and privatization of state assets altered the dynamics between international and domestic forces in the political system (for effects of privatization, see Cerovic and Mitrovic 2007). This, it could be argued, contributed to democratization through multiple effects. First, rapid and poorly implemented liberalization and privatization weakened the Serbian state and further lowered its organizational capacity (Bartlett 2009, 28) to resist external democratizing influences. Or, to borrow the language of Levitsky and Way (2010) and Vachudova (2010), liberalization and privatization increased the leverage that the West exercised over Serbia to implement democratic reforms. Second, the loss of state capacity could be attributed to subsequently blocking the possibility of a roll-back when factions opposed to democratizing influences were elected. Third, through the privatization process, a new elite, which relies on the market instead of the state and can politically and economically compete against entrenched illiberal elements of the old elite, was created. Beginning shortly after the fall of the Milosevic regime, major market reforms were quickly implemented by the new leadership through a process of selling off national industries using a voucher model similar to the post-Soviet model (Milovanovic 2007). This resulted in the subpar valuation of firms sold to preferred insiders and foreign investors, thus creating a powerful new class of political and economic elites (ibid. 224-225) that benefit from those policies affiliated with EU integration.

The latter changes are significant for structuralists because they altered the patterns of relations away from supporting nationalist elements, and towards those conducive to democratic reforms. Along the lines of Levitsky and Way (2010), one could argue that changes to the political economy in Serbia worked to weaken the statist elements of the Serbian state, thereby supporting those liberalizing forces that facilitated linkages with the West. Under a structuralist account, these changes, along with those introduced through closer relations with the EU, were central to creating path dependencies that encourage further and continual alignment with the institutions, norms, and policies of democratization, and discourage actions that jeopardize that alignment. These changes and partnerships work to constrain authoritarian elements and empower democratizing ones. The EU's influence is particularly strong due to the international system's unipolar structure that, along the lines of the argument presented by McFaul (2010), suggested that there was no longer an international actor capable of skewing the domestic balance of power in favour of anti-democratic elements.

\section{Integrating Rational Choice and Structuralist Explanations}

On the basis of the above accounts, I argue that both rational choice and structuralist explanations are necessary for a complete understanding of democratization in Serbia. They explain democratization from different angles and emphasize different units and levels of analysis; hence, in order to understand democratization in Serbia, the two approaches need to be 
brought into conversation with one another. Rational choice approaches give insight into the decisive role political leadership played in overcoming path dependence. Structuralist explanations are more attuned to the role of transnational linkages in facilitating democratization despite setbacks.

In making this argument, this paper builds on the emerging literature that seeks to combine both structuralist and voluntarist accounts in explaining transitions to democracy. Scholars such as Schimmelfennig and Sedelmeier (2005), Vachudova (2005; 2010), and Bunce and Wolchik (2010; 2011) attempt to integrate the two theoretical orientations. Although they vary in their success in doing so systematically, they nonetheless provide contours along which a case study such as this one can combine both structuralist perspectives and voluntarist approaches in accounting for the consolidation of democracy.

As mentioned above, rational choice is necessary to explain the role of leadership in overcoming existing path dependencies and initiating the democratization process. For example, political liberalization at the outset of the reforms (after the fall of the Milosevic regime) cannot be explained but with recourse to the actors that overcome existing power structures and societal norms that supported nationalist, statist, and collectivist orientations. It is true that outside actors played an important part in pressuring actors to adopt democratic measures, but this pressure was not structural at this early stage. Instead, it worked to provide necessary resources (financial, technical) to the pro-democracy actors. ${ }^{6}$

At this stage of the reform process, structures were in flux; I hypothesize that this fluidity gave the pro-democracy faction/leadership decisive agency over the process. Ascribing these changes to domestic institutions as opposed to actors would be problematic, given that the institutions themselves were largely undemocratic. Thus, recourse to the role of actors is essential for understanding how reform was initiated in an illiberal context. Moreover, the cost-benefit analysis that informs rational choice decision-making provides a rationale of why certain actors decided to pursue pro-democracy reforms.

However, there are several ways in which the rational choice approach falls short of providing a complete understanding of democratization in Serbia. First, while the cost-benefit calculus serves to paint a general picture of why political actors came to support democratization, this aggregate picture focuses on elite players to the neglect of wider determinants and trajectories of democratization. How and why did democratization continue after the initial way of popular uprisings, considering that significant segments of the population did not experience the direct benefits of democratization, especially at the time of initial implementation and restructuring? Moreover, the pro-democracy faction has faced numerous setbacks over the years, the most significant of which was the assassination of Prime Minister Djindjic. The benefits of reform were therefore accompanied by significant costs; yet, despite periodic setbacks, democratization efforts have been unfolding over the long run.

Some of the shortcomings within rational choice explanations can be addressed with reference to structuralist accounts that emphasize the role of transnational linkages in facilitating and sustaining democratization. Under this account, once initial decisions were taken to join the

\footnotetext{
${ }^{6}$ For a summary of the support provided by outside actors, see: Vachudova, 2010; Bunce and Wolchik, 2011.
} 
Stability Pact and, consequently, the Stabilization and Association Agreement, and new social patterns were established, it became difficult to completely reverse the democratizing trend. As noted by Vachudova, once a candidate is on its way to joining the EU, "the cost of losing ground or reversing course becomes prohibitive - for any government” (2010, 100). EU linkages laid the groundwork through, for example, creating vested interests and public expectations, the recourse to which was made in instances in which reforms were stalling. While periodic setbacks on the path to democratization have been encountered, and by the European Union's own account, Serbia is lacking on key reforms (see European Commission 2013; European Commission 2014), it is the pace of reforms that is in question, not their direction. The consistent reference to EU membership in public discourse and convergence of all major political players around this goal is an important testament to the strength of the EU's democratizing imperatives. The latter cannot be explained without reference to the structural inducements towards democratization, which are present in political and economic spheres and have been established through the various linkages that connect institutions and people in Serbia to those of the EU.

Moreover, references to transnational linkages are particularly relevant in explaining how domestic institutional constraints were overcome past the initial exercise of agency. While actors were central in initiating reforms at the start of the process, particularly at the time of heightened popular mobilization, the reforms were sustained only with the EU discouraging alternative courses of action and making them more costly - both politically and financially (Levitsky and Way, 2010:112). While it was actors that initiated democratization in the context of a power vacuum, over time, the "positive conditionality" came to constitute an important incentivizing mechanism that made challenging the more formidable domestic constraints to democratization (e.g., institutional ones) possible. The EU assumed leverage over Serbia, and it was this leverage that became not only a carrot, but a stick with which to encourage continuous reform (Pippan 2004, 221-229).

The external character of the structuralist explanation is also noteworthy because it can account for why democratization continued in a domestic institutional context that was not conducive on its own to sustained democratization. Over the long run, democratic reforms continued to be implemented, even though segments of the population did not benefit from the reform effort (such as people employed in previously-state-owned industries), a critical juncture seemed to be reached with the Djindjic assassination, and a campaign for pursuing an alternative to the EU characterized a considerable portion of the public discourse in the first few years of the 2000s (Radeljic 2014). External actors and pressures were crucial in pushing Serbia towards reform. Therefore, whereas the pro-democracy leadership was instrumental in initiating reform, external structural constraints were central in sustaining the reform.

Structuralist approaches are complemented by a rational choice account in the latter's emphasis on agency in the course and pace of democratization. Structuralist accounts can be deterministic, and in the case of international or EU structures, excessively focused on the macro scale without due attention to the interplay between actors at the domestic (meso) and individual (micro) level. Hence, while the structuralist account is integral for emphasizing the patterns of relations between the EU and Serbia, it needs to be supplemented with attention to actors and agency provided by voluntarist accounts. 


\section{Towards a More Complete Account of Democratization in Serbia}

What propels democratic transitions forward? What are the roles of political actors in the process? How do institutions and the international environment encourage or discourage democratization? Answers to these questions have varied depending on the time under consideration and the case studies in question. Whereas the literature on the Third Wave has tended to emphasise the role of actors and negotiations between factions in explaining outcomes, literature of the Fourth Wave has tended to focus on structural factors, particularly the role of the EU in supporting democratization in Eastern and Southeastern Europe.

In contrast to the emphasis in the literature on explaining regime change (specifically the electoral revolutions), this paper builds on the nascent literature that integrates both structuralist and rational choice explanations by focusing on the process of democratic consolidation. Moreover, its contribution lies in detailing the experiences of democratic consolidation in a region whose experience with the legacies of civil war has undoubtedly made democratic consolidation more complex than was the case in the post-communist societies of Eastern Europe. Focusing on Serbia's experience with democratization and taking into consideration the role of political economy where appropriate, it has argued that rational choice approaches give insight into the decisive role of political leadership in overcoming illiberal institutions and undemocratic path dependencies. The structuralist explanations are well-attuned to the transnational linkages that encourage democratization despite domestic setbacks and consistently encourage reform over time. As both approaches focus on different actors and levels of analysis, they need to be combined in order to provide a more complete account. 


\section{REFERENCES}

Balkans in Europe. 2014. What the Election Means for Serbian Democracy. Available at http://www.balkansineurope.org/ [Accessed on March, 19, 2014].

Bartlett, W. 2009. "Regional Integration and Free-trade Agreements in the Balkans: Opportunities, Obstacles and Policy Issues.” Economic Change and Restructuring 42 (3): 25-46.

Bieber, Florian. 2011. "Building Impossible States? State-building Strategies and EU Membership in the Western Balkans.” Europe-Asia Studies 63(10): 1783-1802.

Bunce, Valerie and Sharon Wolchik. 2011. Defeating Authoritarian Leaders in Postcommunist Countries. Cambridge, New York: Cambridge University Press.

Cerovic, B., and R.D. Mitrovic. 2007. "Privatisation Effects: Some Evidence from Serbia." Transition Studies Review 14(3): 469-487.

Cox, Robert W. 1986. "Social Forces, States and World Orders: Beyond International Relations Theory,” in Robert O. Keohane (ed.) Neorealism and Its Critics. New York: Columbia University Press.

Djurdjev, B.S. 2000. "Problems of regional population growth in Serbia.” GeoJournal, 50(2): 133-138.

Edmunds, T. 2008. "Intelligence Agencies and Democratization: Continuity and Change in Serbia after Milosevic.” Europe-Asia Studies 60(1): 25-48.

—. 2009. “Illiberal Resilience in Serbia.” Journal of Democracy 20(1): 128-142.

Elbasani, Arolda. 2008. "EU Enlargement in the Western Balkans: Strategies of Borrowing and Inventing.” Journal of Southern Europe and the Balkans 10(3): 292-307.

European Commission. 1993. “Report on Enlargement.” Bulletin EC S/3-1992.

—. 2008. "Western Balkans: Enhancing the European Perspective.” COM (2008).

_. 2013. "Serbia: 2013 Progress Report.” COM (2013).

—. 2014. “Serbia Progress Report.” COM (2014).

Geddes, B. 2003. Paradigms and Sand Castles: Theory Building and Research Design in Comparative Politics. Ann Arbor: University of Michigan Press.

Gould, J.A., and C. Sickner. 2008. "Making market democracies? The contingent loyalties of post-privatization elites in Azerbaijan, Georgia and Serbia.” Review of International Political Economy 15(5): 740-769.

Gordy, E. D. 2001. “Building a "Normal, Boring" Country: Kostunica's Yugoslavia.” Current History March 2001, 110-113.

—. 2004. "Serbia After Djindjic: War Crimes, Organized Crime, and Trust in Public Institutions.” Problems of Post-Communism 51(3): 10-17. 
Hall, P. A. and R. C. R. Taylor. 1996. "Political Science and the Three New Institutionalisms.” Political Studies 44(5): 936-957.

Jou, W. 2010. "Political Cleavages in Serbia: Changes and Continuities in Structuring Left-Right Orientations.” Southeast European and Black Sea Studies 10:2: 187-206.

Krnjevic-Miskovic, D. 2001. “Serbia's Prudent Revolution.” Journal of Democracy 12(3): 96110.

Lazic, M. and S. Cvejic. 2007. "Class and Values in Postsocialist Transformation in Serbia.” International Journal of Sociology 37( 3): 54-74.

Levi, Margaret. 1997. “A Model, a Method and a Map: Rational Choice in Comparative and Historical Analysis,” in Lichbach and Zuckerman, eds., Comparative Politics: Rationality, Culture and Structure. Cambridge: Cambridge University Press.

Levitsky, S. and Lucan Way. 2010. Competitive Authoritarianism: Hybrid Regimes After the Cold War. Cambridge University Press, New York, USA.

March, J. G. and J. P. Olsen. 1998. “The Institutional Dynamics of International Political Orders.” International Organization 52(4): 943-969.

McFaul, Michael. 2010. “The Missing Variable: The 'International System’ as a Link between Third and Fourth Wave Models of Democratization” in Bunce, Valerie et. al (eds.)

Democracy \& Authoritarianism in the Postcommunist World. Cambridge; New York: Cambridge University Press.

Milovanovic, Milic. 2007. "Property Rights, Liberty, and Corruption in Serbia." The Independent Review 12(2): 213-234.

O’Donnell, Guillermo and Philippe C. Schmitter. 1986. Transformations from Authoritarian Rule: Tentative Conclusions about Uncertain Democracies. Baltimore: John Hopkins University Press.

Pippan, Christian. 2004. “The Rocky Road to Europe: The EU’s Stabilization and Association Process for the Western Balkans and the Principle of Conditionality.” European Foreign Affairs Review 9: 219-245.

Pond, Elizabeth. 2009. “Serbia’s choice.” Survival 51(2): 123-136.

Presnall, A. 2009. "Which Way the Wind Blows: Democracy Promotion and International Actors in Serbia.” Democratization 16(4): 661-681.

Pridham, Geoffrey. 2005. Designing Democracy: EU Enlargement and Regime Change in Postcommunist Europe. Houndmills, Basingstoke, Hampshire; New York: Palgrave MacMillan.

Przeworski, Adam. 1991. Democracy and the Market: Political and Economic Reforms in Eastern Europe and Latin America. Cambridge; New York: Cambridge University Press. 
Radeljic, Branisalv. 2014. “The Politics of (No) Alternatives in Post-Milosevic Serbia.” Journal of Balkan and Near Eastern Studies 16(2): 243-259.

Robinson, William I. 2004. A Theory of Global Capitalism: Production, Class, and State in a Transnational World. Baltimore: John Hopkins University Press.

Schimmelfennig, Frank and Ulrich Sedelmeier, eds. 2005. The Europeanization of Central and Eastern Europe. Ithaca: Cornell University Press.

Schmidt, V. A. 2008. "Discursive Institutionalism: The Explanatory Power of Ideas and Discourse.” Annual Review of Political Science 1: 303-326.

Spoerri, M. 2010. “Crossing the line: partisan party assistance in post-Milosevic Serbia.” Democratization 17(6): 1108-1131.

Vachudova, M.A. 2005. Europe Undivided: Democracy, Leverage and Integration after Communism. Oxford: Oxford University Press.

— 2010. "Democratization in Postcommunist Europe: Illiberal Regimes and the Leverage of the European Union,” in Bunce, Valerie et. al (eds.). Democracy \& Authoritarianism in the Postcommunist World. Cambridge: Cambridge University Press.

Waltz, Kenneth. 1979. Theory of International Relations. Long Grove: Waveland Press, Inc.

Wendt, A. 1999. Social Theory of International Relations. Cambridge: Cambridge University Press.

Weyland, Kurt. 2006. Bounded Rationality and Policy Diffusion: Social Sector Reform in Latin America. Princeton: Princeton University Press.

—. 2010. "The Diffusion of Regime Contention in European Democratization, 1830-1940.” Comparative Political Studies 43(8/9) 1148-1176. 
Published by the Centre for European Studies at Carleton University, Ottawa, Canada Available online at: journals.carleton.ca/rera/index.php/rera

RERA is an electronic academic peer-reviewed journal that publishes graduate, post-graduate, and young scholarly works. Topics relate to the European Union, its Member States, the former Soviet Union, and Central and Eastern Europe. The journal is a joint project supported by the Canada-Europe Transatlantic Dialogue-a cross-Canada research network supported by the Social Sciences and Humanities Research Council of Canada (SSHRC)—along with the Institute of European, Russian and Eurasian Studies (Carleton University) and its associated research unit, the Centre for European Studies.

RERA aims to provide an accessible forum for research, to promote high standards of research and scholarship, and to foster communication among young scholars.

\section{Contact:}

Carleton University

The Centre for European Studies

1103 Dunton Tower

1125 Colonel By Drive

Ottawa, ON K1S 5B6

Canada

Tel: +01 613 520-2600 ext. 3117; E-mail: rera-journal@carleton.ca

\section{Creative Commons License}

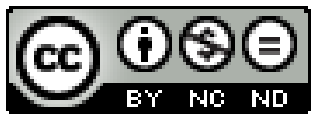

creativecommons.org/licenses/by-nc-nd/3.0

This Working Paper is licensed under a Creative Commons Attribution-Non-CommercialNo Derivs 3.0 Unported License (CC BY-NC-ND 3.0).

Articles appearing in this publication may be freely quoted and reproduced, provided the source is acknowledged. No use of this publication may be made for resale or other commercial purposes.

ISSN: 1718-4835

(C) 2015 The Author(s) 